DOI https://doi.org/10.30525/978-9934-588-90-7-58

\title{
ВЕРБАЛІЗАЦІЯ КОНЦЕПТУ «ПАНДЕМІЯ COVID-19» У ФРАНЦУЗЬКІЙ МОВІ ЯК ПЕРЕКЛАДАЦЬКА ПРОБЛЕМА
}

\author{
Коккіна Л. Р. \\ кандидат філологічних наук, доцент \\ Одеський національний університет \\ м. Одеса, Україна
}

Ситуація з короновірусом, в якій сьогодні опинився весь світ, впливає не тільки на економічний, суспільно-політичний та психічний стан людства. Суттєві зміни відбуваються в майже всіх сферах життєдіяльності. Зокрема, філологічні дисципліни, як-то перекладознавство, отримали нові виклики, оскільки саме переклад сприяє максимальному порозумінню між представниками різних націй. Забезпечення адекватності та оперативності його виконання залежить від вірного сприйняття перекладачами конвергенції та дивергенції актуальних подій, їх відбитку на змінах картин світу географічно віддалених країн.

В більшості випадків, останні трансформації у людському суспільстві носять глобальний характер: міри безпеки; нові правила поведінки в місцях загального перебування; переведення, за можливістю, професійного спілкування та навчання в режим онлайн. Натомість, деякі феномени, появу яких датують 2020 роком, або їх трактування, в різних картинах світу, можуть суттєво різнитися, залежно від країни. Відповідно, це призводить до певних труднощів, в рамках здійснення перекладу. Зазначимо, що велика кількість розробок, присвячених темі лексики COVID-19, зокрема, французькою та українською мовами, 3'явилася, починаючи з березня 2020. ЗМІ масово пропонують читачам добірки головних термінів, дотичних цього захворювання [2]. Словники починають реєструвати лексеми, пов'язані із коронавірусом. Щодо досліджень, виконаних в перекладознавчій площині, які аналізували б головні проблеми міжмовної комунікації, в межах ситуації, яка склалася у світі, то їх кількість, поки що $є$ мінімальною. Безперечно, частково, через те, що найбільший прошарок термінологічного апарату COVID-19 складається 3 інтернаціональної лексики, або англіцизмів, які швидко абсорбувалися іншими мовами. До того ж, слід визнати, що зазначені лексичні одиниці не $є$ досить численними. Однак, проблеми вже існують, і потрібно спрямувати зусилля фахівців на їх вирішення. 
3 огляду на спрямованість такої дисципліни, як «Вступ до перекладознавства», запропонованої до уваги студентів другого року навчання факультету романо-германської філології, всі приклади, які будуть наведені нижче, доцільно включити до практичної частини курсу, як ті, що відображують відповідну діахронію розвитку міжмовних відносин, під час пандемії.

Франкофона термінологія щодо COVID-19 пропонує дещо різні визначення можливої локації людини, під час епідемії/пандемії, в залежності від стану ії самопочуття, в ЗМІ різних країн.

Бельгія: La quarantaine est une mesure de prévention au cours de laquelle une personne ayant peut-être été en contact avec une personne atteinte d'une maladie contagieuse est isolée pendant la période d'incubation de la maladie. Elle peut être forcée ou volontaire. L'isolement est une autre mesure de prévention mais qui concerne les personnes dont l'infection a été avérée. Le malade est dès lors isolé des personnes non infectées durant la période de transmissibilité de la maladie.

Швейцарія: L'isolement si vous êtes atteint d'une maladie aigüe qui peut être causée par le nouveau coronavirus. La quarantaine si vous avez été en contact étroit avec une personne testée positive au nouveau coronavirus.

Канада: L'auto-isolement: Vous ne présentez pas de symptômes et Vous avez voyagé à l'étranger récemment ou avez potentiellement été en contact avec une personne infectée par la COVID-19. La quarantaine: Vous présentez des symptômes, légers ou non et Vous attendez les résultats de votre test de dépistage ou vous avez reçu un diagnostic de COVID-19 récemment.

Франція: L'isolement est une mesure de précaution qui s'applique aux cas possibles, probables et confirmés. Si l'on a été en contact rapproché avec une personne malade, et que des symptômes apparaissent, il faut se faire tester immédiatement et attendre les résultats. Une quarantaine est un isolement provisoire imposé à des personnes, navires ou animaux provenant d'un pays infecté par une maladie contagieuse, selon la définition $d u$ dictionnaire Larousse.

Слід зазначити, до того ж, що у Франції, починаючи з березня 2020 не вщухали дебати щодо термінів иne quarantaine та une quatorzaine. Більш того, у вересні 2020 період вимушеного перебування вдома було скорочено до 7 днів, відповідно, починається оперування новим терміном: la septaine.

3 наведеного стає зрозумілим, чому, через розбіг у дефініціях таких актуальних понять, доволі часто виникають невірні трактування ситуації 3 епідемією в окремих країнах, під час висвітлення новин ЗМІ. Також, можуть виникнути проблеми у громадян України, які мають намір 
відвідати іноземну державу, і намагаються отримати правила перетину кордонів для іноземців, під час пандемії, на офіційних сайтах країн, українською мовою.

Незаперечним $\epsilon$ той факт, що будь-які нові явища у суспільстві $\epsilon$ запорукою появи нових лексичних одиниць, приналежність яких до класу неологізмів, сленгізмів чи оказіоналізмів може бути вирішена, вочевидь, лише $з$ плином певного часу, особливо, зважаючи на те, що досі не існує чіткої та одностайно визнаної класифікації для диференціації цих категорій [1].

Так, носії французької мови в різних країнах винайшли різноманітні найменування для номінації захисних масок, які в повній мірі відбивають реалії просторової локалізації мовців [5]. Наприклад, в Алжирі та інших африканських країнах, це достатньо комічна назва une bavette, що українською перекладається, буквально, як слинявчик. Для мешканців Браззавілю (Конго), є два розповсюджених найменування для захисного засобу: un passeport (nacnopm), через тотожність, за значущістю, до документу, відсутність якого є передвісником проблем 3 поліцейськими, або un cache-nez (шарф), за аналогією з елементом одягу, шматком тканини, яким місцеві жителі захищають обличчя під час сезонних вітрів. Un couvre-visage (покриття для обличчя) є офіційно визнаним терміном на позначення захисної маски у Канаді. У Буркіна-Фасо послуговуються словом un anti-corona. Un toucan (тукан) - номінація, що прижилася у Габоні, через масове використання такого виду маски як FFP2. Un cachemisère (пристойний одяг, щу ховає лахміття) - інший синонім слова маска, який вживають канадці, коли говорять про маску як про аксесуар, що допомагає заховати недоліки шкіри, акне, тощо. Сучасна молодь Франція продовжує традицію використання verlan (кодованої мови «навпаки»), задля перетворення un masque на un skeuma, un skeum. В України, у сьогоденні, оперують лише такими поняттями як: маска, захисна маска, намордник, тобто відповідник може бути дібрано лише оказіональний.

Також, поняття un couvre-feu (комендантська година), яка ввійшло, цього року, в лексикон мешканців багатьох франкомовних країн, може виявитися декілька далеким від реалій україномовного читача, оскільки зазначену запобіжну міру було введено в Україні у березні-квітні 2020, на короткий термін, до того ж, іiі недотримання суворо не каралося. Відповідно, подекуди, без перекладацького пояснення, розуміння, наприклад, новин, може бути неповним або хибним.

Цікавим для обговорення зі студентами $є$ той факт, що у Франції, провідною науковою установою щодо питань мови, Французькою 
академією, після жвавих суперечок, було офіційно затверджено жіночий рід за іменником covid (f) [3]. Натомість, інші сучасні французькі мовознавці вказують на те, що наразі занадто рано говорити про остаточне рішення, відносно жіночого або чоловічого роду цього терміну, спираючись на його етимологію [4].

Невід'ємною частиною людини завжди був та залишається гумор, який відрізняє іiі від інших представників тваринного світу, та притаманний, навіть у самих тяжких ситуаціях. Так, випадок зі стрімким поширенням пандемії у світі, не став виключенням, і згенерував значну кількість інтернет мемів, карикатур, анекдотів, вірусних відео в соціальних мережах. Але, саме відмінності у протіканні пандемії в кожній конкретній країні можуть стати чинником нерозуміння тонкощів гумору, через локальну складову, навіть, якщо людина володіє іноземною мовою.

На меті цього зіставлення $є$ донесення до студентів постулату про важливість доперекладацького аналізу, залучення широкого контексту для вірного відтворення швидкоплинного потоку інформації, коли те, що може здаватися постійним відповідником, виявляється, серед, так званих «faux amis», особливо, для початківця.

\section{Література:}

1. Дзюбіна О.I. Визначення статусу новостворених лексичних одиниць в англомовному сегменті соціальних мереж Twitter та Facebook. URL: http://essuir.sumdu.edu.ua/handle/123456789/59511 (дата звернення 24.10.2020).

2. Cougnon, L., \& de Viron, L. (2020, July 30). Covid-19 et communication de crise. Focus linguistique sur les tweets francophones de Belgique. URL: https://doi.org/10.31235/osf.io/3qrcw (дата звернення 24.10.2020).

3. Le covid 19 ou la covid 19. URL : http://www.academie-francaise.fr/lecovid-19-ou-la-covid-19 (дата звернення 11.10.2020).

4. Que veut dire le mot Covid-19? URL: https://dictionnaire.orthodidacte.com/article/definition-covid-19 (дата звернення 12.10.2020).

5. L'humeur de Linda : quels sont les points communs entre le cache-nez, le passeport et le toucan ? URL : https://information.tv5monde.com/video/lhumeur-de-linda-quels-sont-les-points-communs-entre-le-cache-nez-lepasseport-et-le-toucan (дата звернення 25.10.2020). 